\title{
İri Agrega Olarak İnşaat Yıkıntı Atığı, İnce Agrega Olarak Doğal ve Kırma Kum Kullanılan Betonun Bazı Mühendislik Özelliklerinin İncelenmesi
}

\section{Investigation of Some Engineering Properties of Concrete Using Construction Wreckage Waste as Coarse Aggregate, Natural and Crushed Sand as Fine Aggregate}

\author{
Mustafa Kürşad Korkut $^{1}$ iD ${ }^{\text {Osman Şimşek }}{ }^{1}$ (D) \\ ${ }^{I}$ Gazi Üniversitesi Teknoloji Fakültesi 06500 Teknikokullar / Ankara, TÜRKIYE
}

Başvuru/Received: 12/02/2021

Kabul / Accepted: 25/03/2021

Çevrimiçi Basım / Published Online: 23/05/2021

Son Versiyon/Final Version: 18/06/2021

\section{$\ddot{O} \mathbf{z}$}

Günümüz inşaat sektöründe en önemli yapı malzemesinden biri betondur. Beton malzemesinin önemli sorunları vardır. Bu sorunların başında kaliteli agrega temini, ikincisi ise inşaat yıkıntı atıklarının çevre kirliliği ve sürdürülebilirliğidir.

İri agrega olarak inşaat yakıntı atığından (IYA) elde edilen ve ince agrega olarak kırma kum (KK) ve doğal kum (DK) kullanımlarıyla farklı oranlarda yüksek performanslı süper akışkanlaştırıcı kullanılarak beton üretilmiştir. Beton karışımında agrega olarak yıkıntı atığı agregası (YAA) $(4-11,2) \% 24,(11,2-22,4) \% 29$ ve ince agrega DK ve KK $(0-4) \% 47$ oranlarında kullanılmıştır. Bağlayıcı olarak CEM I 42,5 R çimentosu ve yüksek performanslı süper akışkanlaştırıcı miktarı ise çimento ağırlığının $\% 0, \% 1, \% 1,5$ ve $\% 2$ oranlarında kullanılarak beton üretilmiştir. Üretilen betonların işlenebilirlik, basınç ve yarmada çekme dayanımları, aşınma, kılcal su emme oranları ve boy değişimleri gözlenmiştir.

YAA yanında kullanılan DK ile üretilen betonun işlenebilirliği yüksek iken diğer mekanik ve fiziksel özelliklerinin çalışmanın en düşük özelliklerini gösterdiği görülmüştür. KK ile üretilen beton karışımında işlenebilirliğin azalmasına karşın mekanik ve fiziksel özellikleri çalışmanın en yüksek performansa sahip değerler sergilediği saptanmıştır.

\section{Anahtar Kelimeler}

"Ylkıntı atı̆̆ agregası, basınç dayanımı, kapiler su emme, serbest rötre"

\begin{abstract}
Concrete is one of the most important building materials in today's construction industry. Concrete material has important problems. The first of these problems is to supply quality aggregate and the second is the environmental pollution and sustainability of construction wreck wastes. Concrete was produced by using high performance super plasticizer in different proportions, using crushed sand (KK) and natural sand (DK) as fine aggregate and coarse aggregate obtained from construction wreck waste (IYA). YAA (4-11.2) 24\%, (11.2-22.4) 29\% and fine aggregate DK and KK (0-4) 47\% were used as aggregates in the concrete mixture. Concrete was produced by using CEM I $42.5 \mathrm{R}$ cement as the binder and the amount of high-performance super plasticizer at $0 \%$, $1 \%, 1.5 \%$ and $2 \%$ of the cement weight. Workability, compression and splitting tensile strength, abrasion, capillary water absorption rates and length changes of the concrete produced were observed. It has been observed that the workability of concrete produced with DK used in addition to YAA is high, while other mechanical and physical properties show the lowest properties of the study. Although the workability of the concrete mixture produced with KK has decreased, it has been determined that the mechanical and physical properties of the work have the highest performance values.
\end{abstract}

Key Words

"Construction wreck waste,compressive strenght, capillary water absorption, free shrinkage" 


\section{Giriş}

Günümüz dünyasının en önemli sorunlarından birisi olan kaliteli hammaddeye ulaşmada sınırlılık olmakla berber ikincisi ise inşaat yıkıntı atıklarının çevre kirliliğidir. Dünya genelinde sürdürülebilir inşaat faaliyetleri için gerekli hammaddelerin karşılanmasının yanında, inşaat yıkıntı atıklarının kullanımının yaygınlaştırılmasına yönelik çalışmaların teşvik edildiği bilinmektedir. İnşaat yıkıntı atığı sorunlarına yönelik çözümlerden birisi bu atıkların tekrar kullanımı ile çevre kirliliğinin azaltılmasının yanında sürdürülebilirlik olarak değerlendirilmesidir. Özellikle birçok ülkede, inşaat yıkıntı atıklarının (IYYA) geri dönüştürülerek tekrar kullanımının araştırılmasına öncelik kazandırılmıştır. (Esra \& Şenol, 2008).

Yükselen görkemli binalar, inşa edilen asfalt yollar ve restore edilen yerleşkeler dikkate değer bir atık yoğunluğunun oluşmasına neden olmuştur. Avrupa Komisyonu'nun 1999 yılında hazırladığı raporda, 15 üye ülkede 350 milyon nüfusla her yıl yaklaşık 180 milyon ton IYYA üretildiği görülmektedir. Ortalama olarak bu atığın \%28' i geri dönüştürülmekte ve \% $78^{\prime}$ i depolanmaktadır. Almanya, Birleşik Krallık, Fransa, İtalya ve İspanya tarafından üretilen IYYA’ lar, AB üye devletlerinin ürettiği atığın yaklaşık \%80' ini oluşturmaktadır. Hollanda, Belçika ve Danimarka, IYYA’ ların geri dönüştürülmesinde büyük başarı elde eden ülkelerdir (Esra \& Şenol, 2008; Maçin \& Demir, 2018). Lauritzen (1994) Belçika'da \%40'ı beton, \%40'1 tuğla, \%12'si bitümlü briket, \%3,4'ü seramik olmak üzere yaklaşık 4,6 milyon ton inşaat ve yıkım atığı olduğunu vurgulamaktadır.

Türkiye'de son 10 yılda gerçekleşen en fazla can ve mal kaybına sebebiyet veren depremlerden birisi 2011 yılında olan Van depremidir. Bu deprem sonrasında ülkemizdeki yapılaşmanın, standartların altında kaldığı acı bir tabloyla gün yüzüne çıkmıştır. Depremi takip eden yılda, 31.03.2012 tarih 6306 sayılı Afet Riski Altındaki Alanların Dönüştürülmesi Hakkında Kanun ile şehirlerimizde ve ilçelerimizde Çevre ve Şehircilik Bakanlığımızca yürütülen kapsamlı çalışmalar sonucunda riskli yapılar ve alanlar ilan edilip, restorasyonlara ve yeni yapılaşmalara başlanmıştır (Ölmez \& Yıldız, 2008; Maçin \& Demir, 2018; Resmi gazete, 2012).

Devlet Planlama Teşkilatı VIII. 5 Yıllık Kalkınma Planı (2001 -2005) raporunda belirtildiği üzere; İnşaat-yıkım ve hafriyat atıkları: 17 Ağustos ve 12 Kasım 1999 tarihlerinde meydana gelen depremlerde yapılan hasar tespiti sonucunda yaklaşık 43.000 binanın yıkıldığ 1 ve çok büyük miktarda inşaat atığının meydana geldiği tespit edilmiştir. Yaklaşık 13 milyon ton moloz oluştuğu tahmin edilmektedir. Bu atıklar Çevre Bakanlığı ve Çevre İl Müdürlüklerinin belirlediği yerlerde depolanmış, bir kısmı ise depremin ilk günlerinde denize dökülmüştür. Söz konusu raporun “Karşılaşılan sorunlar ve çözüm önerileri” bölümünde inşaat yıkıntı atıklarıyla ilgili önerilerden ilki doğal afetlerle ilgili yasal düzenlemeler olup, afet, yıkıntı ve atıkların yönetiminin de dikkate alınarak yeniden düzenlenmesine yönelik. İkincisi de bölgesel moloz yönetimine dair bir plan hazırlanmasına yöneliktir ve bu program doğrultusunda molozlardan demir, çimento ve çakıl geri kazanımına yönelik yapılacak çalışmaların önemi vurgulanmaktadır. Bu raporun çözüm önerisi olarak” molozlardan demir, çimento ve çakıl geri kazanılmalı" yer almaktadır (DPT, 2000). Mevcut yapı stokunun 2000 yılından öncekilerin çoğunluğu depreme dayanıksız olduğu yaşanan depremler neticesinde anlaşılmaktadır. Bu nedenle hızlı şehirleşme nedeniyle yapı stokunun yenilenmesi, kentsel dönüşümün önemi artmıştır.

Devlet Planlama Teşkilatı IX. 5 Yıllık Kalkınma Planı (2007 -2013) raporunda belirtildiği üzere; doğal kum çakıl oranı belirli oranda azalma gösterirken, kırma agrega (kırma taş agrega) üretim oranı yani kullanım oranının oldukça arttığı raporlandırılmıştır (DPT, 2007). Raporda belirtildiği gibi kaliteli, taş ocaklarına bağlı kırma agrega kullanımının artması hem maliyeti artırmakta hem de doğal topoğrafik yapıyı bozarak çevre kirliğine neden olmaktadır. Betondan belirli bir kalite standardı istenmesi, beton teknolojisindeki ilerlemeye paralel olarak, betonun iskeletini oluşturan agrega kalitesini de ön plana çıkarmaktadır. DPT raporunda bahsedildiği gibi kaliteli agrega sıkıntısı çekilen yerlerde veya çevre kirliliğinin azaltılması amacıyla yüksek dayanım istenmeyen (kaldırım, su geçirgen beton, saha betonu, şehir içi açık otopark vb.) yerlerde, atık betonların kırılmasıyla elde edilen geri dönüşüm agregası (GDA) kullanarak üretilen betonlar kullanılabilir. Genel olarak GDA iki şekilde elde edilmektedir. Bunlardan birincisi atık betonların kırılarak agregaya dönüştürülmesiyle elde edilen geri dönüşüm agregası, ikincisi ise inşaat yıkıntı atığı (moloz) olan kâgir malzemelerden elde edilen inşaat yıkıntı atığı agregasıdır (İYAA). Bu konularda son yıllarda çalışmalar yaygınlaşmıştır.

GDA tanelerinin çimento hamurundan oluşması, doğal agrega yüzeyiyle etkileşime girmesi sonucuyla ortaya çıkan betonun agrega tane boyutuna getirilmesi ile oluşur. Bu çimento hamurunun miktarı, su emilimi, yoğunluk, aşınma direnci ve çimento hamuru ile agreganın yapışması gibi olguların GDA performansını etkilediği görülmüştür. GDA' nın içi boş yapısı ve yüzeyinde bulunan eski harç tabakası nedeniyle doğal agregaya göre daha düşük yoğunluk ve daha yüksek su emme oranına sahiptir. Çalışmada doğal agreganın su emme oranı \%0,5 ile \%1 arasında değişirken, GDA’ nın su emme oranı \%4 ila \%12 arasında değiştiği belirtilmiştir (Çelik, 2001; Kou, Poon \& Chan, 2007)

Yapılan araştırmalarda atık betonun kalitesi GDA' nın kalitesi ile direk bağlantılı olduğu vurgulanmıştır. Genel olarak GDA' nın teknik özelliklerinden su emme oranı ve aşınma kaybının beklentilerin üzerinde olduğu, ancak yoğunluklarının beklenilenden daha az olduğu araştırma sonucu tespit edildiği belirtilmiştir. GDA ile üretilecek betonun basınç dayanımı, agreganın elde edildiği betonun bir alt beton sınıfını karşılayabileceği açıklanmıştır. Bununla birlikte GDA ile üretilen betonların elastisite modülü ve basınç dayanım değerlerinin geri dönüştürülmemiş betonun çimento miktarına, dolayısıyla su/çimento (S/Ç) oranına, agrega kalitesine, dolayısıyla betonda oluşan boşluklarına ve çimento harcı ile oluşan agrega hamur aderanslarına bağlı olduğu vurgulanan önemli hususlar olarak tespit edilmiştir (Demirel, Toklu \& Şimşek, 2015; Sonawane \& Pimplikar, 2013) 
Demirel \& Şimşek (2014) yaptıkları çalışmada, C25 sınıfı olan atık betonlardan elde edilen iri ve ince agregaların betonda kullanım olanaklarını araştırmışlardır. Bu atık beton agregasını iri ve ince olarak iki gruba ayırmışlardır. Araştırmada çimento yerine $\% 20$ oranında uçucu kül (UK) ikame edilmiştir. Karışımda işlenebilirliği sağlamak için çimento kütlesinin \%1,2' si oranında süper akışkanlaştırıcı (SA) ilavesi yapılmıştır. Yapılan deneylerin sonuçlarına göre geri dönüşüm agregalarının beton üretiminde kullanılabilirliği tespit edilmiştir.

Durmuş vd. (2009), atık betondan elde edilen geri dönüşüm agregası ile üretilen beton üzerinde birim hacim ağırlık, ultra ses ve basınç deneyleri yapmışlardır. Geri dönüşüm agregalarının tamamı beton içerisinde kullanılmak istendiğinde beton tasarımında bir üst beton sinıfı kriterlerine göre hesaplanması vurgulanmıştır.

Süme (2016) yaptığı çalışmada inşaat yıkıntı atıklarının (IYYA) geri dönüşümünün sağlanarak beton yol kaplamasında kullanılabilirliği üzerinde durmuştur. \%100 temizlenmiş geri dönüşüm agregası (TGDA), \%100 normal agrega (NA) ve geri dönüşüm agregasının (GDA) beton karışımına ağırlıkça \%20, 40, 60, 80 oranında ikame edilerek üretilen betonun mekanik özellikleri araştırılmış. Bu mekanik özeliklerden eğilmede çekme ve basınç dayanımları belirlenmiş ve bulunan değerler karşılaştırılmıştır. GDA kullanım oranı arttıkça beton basınç dayanımının arttığı, eğilmede çekme dayanımının ise inişli çıkışlı bir grafik gösterdiği, \%100 TGDA ile üretilen betonun eğilmede çekme ve basınç dayanımı diğer üretilen deney grupları arasında maksimum sonucu verdiği belirtilmiştir.

Son yıllarda meydana gelen doğal (deprem) felaket sonuçlarında meydana gelen molozlar için vahşi depolama yöntemi kullanıldığı bilinmektedir. Doğal felaketler dışında, inşaat yıkıntı atıkları, bazı ülkelerde sürdürebilirlik açısından veya bazıları da kaliteli doğal kaynak sıkıntısından dolayı, bu yıkıntı atıklarını kırma eleme işleminden sonra geri dönüşüm malzemesi olarak farklı yerlerde, farklı amaçlar doğrultusunda kullanabilmektedirler. İnşaat yıkıntı atıklarında kâgir kökenli (beton, kiremit sıva, boya ve duvar) malzemeleri agrega olarak beton üretiminde kullanılmaktadır.

Bu çalışmanın amacı; İri yıkıntı atığı agregasının beton üretiminde, elde edilecek olan betonun taze ve sertleşmiş özelliklerine etkisini incelemektir. Bu amaçla; inşaat yıkıntı atığı molozları taşıyıcı olmayan beton üretiminde kullanılmak üzere molozlardan kırılarak elde edilen yıkıntı atığı agregası (YAA) (4 -22) çakıl ile doğal kum (DK) (0-4) ve kırma kum (KK) agrega karışımıyla C 20 sınıfı beton tasarımı yapılarak bazı teknik özellikleri incelenmiştir.

\section{Materyal ve Metot}

\subsection{Materyal}

Yapılan bu araştırmada, YAA elde edilerek, iri agrega $(4-22 \mathrm{~mm})$ olarak kullanılmış olup, ince agrega (0-4mm) olarak DK ve KK olmak üzere üç tip agrega kullanılmıştır. Bağlayıcı olarak CEM I 42,5 R kullanılırken işlenebilirlik için hiperakışkanlaştırıcı kimyasal katkı maddesi, şehir şebekesi suyu ile karışımlar hazırlanmıştır.

\subsubsection{Bă̆layıcı ve karışım suyu}

Çimentoya ait yoğunluk değeri 3,10 kg/dm3 dür ve CEM 1 42,5 R çimentosunun kimyasal özellikleri Tablo 1'de verilmiş olup beton karışımında Ankara ilinin şebeke suyu kullanılmıştır.

Tablo 1. CEM 142,5 R Çimentosuna ait teknik özellikleri

\begin{tabular}{llllllllll}
\hline Oksitler & $\mathbf{S i O}_{\mathbf{2}}$ & $\mathbf{A l}_{\mathbf{2}} \mathbf{O}_{\mathbf{3}}$ & $\mathbf{F e}_{\mathbf{2}} \mathbf{O}_{\mathbf{3}}$ & $\mathbf{C a O}$ & $\mathbf{M g O}$ & $\mathbf{S O}_{\mathbf{3}}$ & $\mathbf{N a}_{\mathbf{2}} \mathbf{O}$ & $\mathbf{K}_{\mathbf{2}} \mathbf{O}$ & K.Kaybı \\
\hline$(\%)$ & 20,7 & 6,0 & 2,4 & 63,6 & 2,6 & 2,1 & 0,1 & 0,9 & 1,4 \\
\hline
\end{tabular}

\subsubsection{Kimyasal katkı maddesi}

Yapılan çalışmalarda kimyasal katkı malzemesi olarak modifiye polikarboksilat esaslı yüksek performanslı süper akışkanlaştırıcı kullanılmıştır. Söz konusu akışkanlaştırıcı tipi ve oranları karışımda kullanılan agregadan dolayı seçilerek üretici firmanın önerdiği çimentonun ağırlı̆̆ının \%0,4 - \%2 oranlarında üst limitine yakın oranlarla kullanılması tercih edilmiştir. Bu tercihte, taze beton kıvamının agrega ve beton sınıfına bağlı olarak, karışım çökmesinin 3-8 cm arasında olması hedeflenmiştir. Katkı maddesinin teknik özellikleri Tablo 2' de verilmiştir.

Tablo 2. Kimyasal katkı malzemesinin teknik özellikleri (Sika)

\begin{tabular}{l|l}
\hline Tip & Modifiye polikarboksilat esaslı polimer \\
Görünüm & Açık kahve renkli sıvı \\
Yoğunluk $\left(\mathrm{kg} / \mathrm{dm}^{3}\right)$ & $1,10 \pm \pm 0,02$ \\
pH & $3-7$ \\
Suda Çözünebilir Klorür Yüzdesi Maksimum & $0,1 \%$, klorür içermez (TS EN 934-2) \\
Dozaj aralığı $(\%)$ & $0,4-2$ \\
\hline
\end{tabular}




\subsubsection{Araştırmada kullanılan agreganın teknik özelikleri}

YAA, DK ve KK üzerinde yapılan elek analizi sonuçları Tablo 3'de verilmiştir. Agreganın, yoğunluk, su emme oranı, aşınma dayanımı, çok ince tane miktarı (metilen mavisi) ve yassılık endeksi deney sonuçları Tablo 4'de verilmiş̧ir. Tablo 4'de görüldüğü gibi doğal kumun yoğunluğu kırma kumun yoğunluğundan daha düşüktür. Bu agrega grubu, bünyesinde farklı özeliklerde taneleri bulundurması sonucu yoğunluk değerinin düştüğü düşünülmekte, bu literatüre uygunluk göstermektedir (Şimşek, 2020). Doğal kumun su emme yüzdesi, kırma kumdan düşüktür, bu olgu aslında genel olarak yoğunlukla paralellik göstermektedir ve bu durum, aynı özeliklerdeki agregalar için de geçerlidir. Genel olarak, kırma kumun yüzey alanının doğal kumunkine göre fazla olmasından ve aynı zamanda kırılma özelliğinden dolayı doğal agregalara göre daha yüksek su emme değerine sahiptir. Aynı cins agregaların yoğunlukları ile su emme yüzdeleri arasında ters ilişki olduğu bilinmektedir. Kırma agreganın kirlilik oranı (ince tane miktarı) doğal kumdan daha fazla olmasına karşın standart limitin altındadır. Yıkıntı atığı agreganın aşınma direnci ve yassılık indeksi ilgili standartlarda verilen sınırların içindedir.

Tablo 3. Agreganın elek analizi

\begin{tabular}{|c|c|c|c|c|c|c|}
\hline \multirow{2}{*}{$\begin{array}{l}\text { Elek } \\
(\mathrm{mm})\end{array}$} & \multirow[t]{2}{*}{ Çapı } & Doğal Kum & Kırma Kum & YAA ( İnce Çakıl ) & YAA(İri Çakıl) & İdeal Granülometri \\
\hline & & \multicolumn{2}{|l|}{$0-4(\% 47)$} & $4-11,2(\% 24)$ & $11,2-22,4(\% 29)$ & $0-22,4$ \\
\hline 22,4 & & 100 & 100 & 100 & 100 & 100 \\
\hline 16 & & 100 & 100 & 100 & 85 & 86 \\
\hline 11,2 & & 100 & 100 & 98 & 5 & 71 \\
\hline 8 & & 100 & 100 & 72 & 0 & 62 \\
\hline 4 & & 100 & 100 & 5 & 0 & 47 \\
\hline 2 & & 75 & 70 & 0 & 0 & 35 \\
\hline 1 & & 45 & 55 & 0 & 0 & 24 \\
\hline 0,5 & & 10 & 25 & 0 & 0 & 16 \\
\hline 0,25 & & 2 & 10 & 0 & 0 & 6 \\
\hline
\end{tabular}

Tablo 4. Agregaların fiziksel özellikleri

\begin{tabular}{lllll}
\hline Agrega grupları & $0-4 \mathrm{~mm}$ & & $4-11,2 \mathrm{~mm}$ & $11,2-22,4 \mathrm{~mm}$ \\
\cline { 2 - 5 } & $\mathrm{DK}$ & $\mathrm{KK}$ & YAA & YAA \\
\hline Yoğunlukları $\left(\mathrm{kg} / \mathrm{dm}^{3}\right)$ & 2,41 & 2,68 & 2,40 & 2,36 \\
Su emme $(\%)$ & 1,9 & 2,80 & 4,52 & 4,72 \\
Aşınma direnci kaybı(\%) & - & - & 9 & 13 \\
Metilen mavisi (\%) & 2 & 3 & - & - \\
Yassllik endeksi (\%) & - & - & 5,2 & 7,7 \\
\hline
\end{tabular}

\subsection{Metod}

Araştırmada kullanılan agregaların tane büyüklüğü dağılımı TS EN 933-1(2015)' e göre (0-4mm), (4-11,2mm) ve (11,2-22,4mm) agrega gruplarının elek analizleri yapılmıştır. Agregaların tane yoğunluğu ve su emme özelliklerinin belirlenmesinde TS EN 1097 6(2015), yassilık endeksinin belirlenmesinde TS EN 933-3 (2015), parçalanma direncinin belirlenmesinde TS EN 1097-2 (2015) standartları esas alınmıştır. Ayrıca, ince tanelerin tayini - metilen mavisi deneyi ise TS EN 933-9+A1:2013 (2014) standardı baz alınarak yapılmışırır.

Beton tasarımında, beton sınıfı C20 planlanmış ve karışım hesabı TS 802(2016) esas alınarak yapılmıştır. Karışımda üç farklı agrega grubu kullanılmıştır. Bu agrega grupları, ideal granülometriye göre ince agrega $(0-4 \mathrm{~mm})$ oranı \% 47 , yıkıntı atığ agrega 1. grubu (4$11,2 \mathrm{~mm})$ oranı $\% 24$ ve yıkıntı atığı agrega 2 . grubu $(11,2-22,4 \mathrm{~mm})$ oranı ise $\% 29$ olarak hesaplanmıştır.

Taze betonların çökme (slump) özelliği için TS EN 12350-2 (2019) esas alınmıştır.

Sertleşmiş beton özelliklerinden, basınç dayanım testleri 7 ve 28 günlük numuneler, diğer özelliklerin tayini için ise 28 günlük numuneler kullanılmıştır. Betonun basınç dayanımı TS EN 12390-3 (2019) standardı esas alınarak yapılmıştır. Kapiler su emme değerlerini belirlemek için 100x100x100 mm boyutlarındaki numuneler üzerinde TS EN 772-11(2012) standardı uygulanmıştır. Aşınma direncinin tayini için ASTM C944/944M-19 (2019) standardı kullanılmıştır. Serbest rötre özelliği 100x100x300mm beton prizma numuneler üzerinde TS ISO 1920(2011) standardı esas alınarak yapılııştır. Yarmada çekme dayanım testleri TS EN 123906(2010) standardına göre yapılmıştır.

\subsubsection{Beton karışımı tasarımı}

Çalışmada beton tasarımı C 20 sınıfı olarak hedeflenmiştir. Beton karışım hesabı standardı TS 802, (2016) kullanılarak S/Ç oranı 0,60 ve su miktarı 203 lt olarak seçilmiştir. Hesaplamalar doğrultusunda çimento miktarının $338 \mathrm{~kg} / \mathrm{m}^{3}$ olduğu tespit edilmiştir. İşlenebilirliği sağlamak amacıyla çimento ağırlığının \%0, \%1, \%1,5 ve \%2 oranında yüksek performanslı süper akışkanlaştırıcı katkı maddesi eklenmiştir. 
Üretilen karışımların basınç dayanımları TS EN 12390-3 (2019) ve rötre özellikleri TS ISO 1920-8.(2009) esas alınarak yapılmıştır. Taze betonda slump (çökme) testi TS EN 12350-2 (2019) ve kapiler su emme testi TS EN 772-11(2012) göre yapılmıştır.

Beton basınç dayanımında 7 ve 28 günlük deneyler için her bir karışımda 3' er tane olmak üzere toplamda 6 adet 100x 100x 100mm küp numune, serbest rötre deneyi için 3' er tane 100x100x280mm dikdörtgen prizma ve kapiler su emme deneyi için 3 adet 100x100x100mm küp numuneler kullanılmıştır.

Tablo 5. Beton karışım tasarım ve karışım oranları

\begin{tabular}{|c|c|c|c|c|c|c|c|c|c|c|c|}
\hline \multirow{3}{*}{$\begin{array}{l}\text { Beton } \\
\text { Karışımları }\end{array}$} & \multicolumn{4}{|c|}{ Agrega grupları (\%) } & \multirow[b]{2}{*}{ : } & \multirow[b]{2}{*}{$\overrightarrow{\tilde{s}}$} & \multirow{2}{*}{ 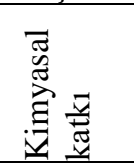 } & \multirow{2}{*}{$\begin{array}{l}0-4 \\
\text { DK }\end{array}$} & \multirow{2}{*}{$\begin{array}{l}0-4 \\
\text { KK }\end{array}$} & \multirow{2}{*}{$\begin{array}{l}4-11,2 \\
\text { YAA }\end{array}$} & \multirow{2}{*}{$\begin{array}{l}11,2-22,4 \\
\text { YAA }\end{array}$} \\
\hline & $0-4$ & & $4-11,2$ & $11,2-22,4$ & & & & & & & \\
\hline & DK & KK & YAA & YAA & $\mathrm{kg} / \mathrm{dm}^{3}$ & $\mathrm{dm} / \mathrm{dm}^{3}$ & $\mathrm{~kg} / \mathrm{dm}^{3}$ & $\mathrm{~kg} / \mathrm{dm}^{3}$ & $\mathrm{~kg} / \mathrm{dm}^{3}$ & $\mathrm{~kg} / \mathrm{dm}^{3}$ & $\mathrm{~kg} / \mathrm{dm}^{3}$ \\
\hline DK-0 & 47 & 0 & 24 & 29 & 338 & 203 & - & 759 & - & 386 & 462 \\
\hline DK- 1,0 & 47 & 0 & 24 & 29 & 338 & 203 & 3,38 & 756 & - & 384 & 460 \\
\hline DK-1,5 & 47 & 0 & 24 & 29 & 338 & 203 & 5,07 & 753 & - & 383 & 459 \\
\hline DK-2,0 & 47 & 0 & 24 & 29 & 338 & 203 & 6,76 & 751 & - & 382 & 458 \\
\hline KK-0 & 0 & 47 & 24 & 29 & 338 & 203 & - & - & 844 & 386 & 462 \\
\hline KK-1,0 & 0 & 47 & 24 & 29 & 338 & 203 & 3,38 & - & 840 & 384 & 460 \\
\hline KK-1,5 & 0 & 47 & 24 & 29 & 338 & 203 & 5.07 & - & 838 & 383 & 459 \\
\hline KK-2,0 & 0 & 47 & 24 & 29 & 338 & 203 & 6,76 & - & 835 & 382 & 458 \\
\hline DK-KK-0 & 23,5 & 23,5 & 24 & 29 & 338 & 203 & - & 379 & 422 & 386 & 462 \\
\hline DK-KK-1,0 & 23,5 & 23,5 & 24 & 29 & 338 & 203 & 3,38 & 378 & 420 & 384 & 460 \\
\hline DK-KK-1,5 & 23,5 & 23,5 & 24 & 29 & 338 & 203 & 5.07 & 377 & 419 & 383 & 459 \\
\hline DK-KK-2,0 & 23,5 & 23,5 & 24 & 29 & 338 & 203 & 6,76 & 375 & 418 & 382 & 458 \\
\hline
\end{tabular}

\section{Bulgular ve Tartışmalar}

\subsection{Taze Betonun İşlenebilme Özelliği}

Yapılan bu çalışmada, doğal kum, kırma kum ve doğal kumu + kırma kum karışımları ile oluşturulan beton karışımlarının işlenebilirliğinin incelenebilmesi amacıyla çökme (slump) deneyi yapılmışırı. Bütün karışımlarda sabit su miktarıyla, işlenebilirliği sağlamak için çimento ağırlı̆̆ının $\% 0, \% 1, \% 1,5$ ve $\% 2$ oranlarında yüksek performanslı süper akışkanlaştırıcı kullanılmıştır. Numuneler üzerinde yapılan çökme deneyi sonuçları Şekil 1' de gösterilmiştir.

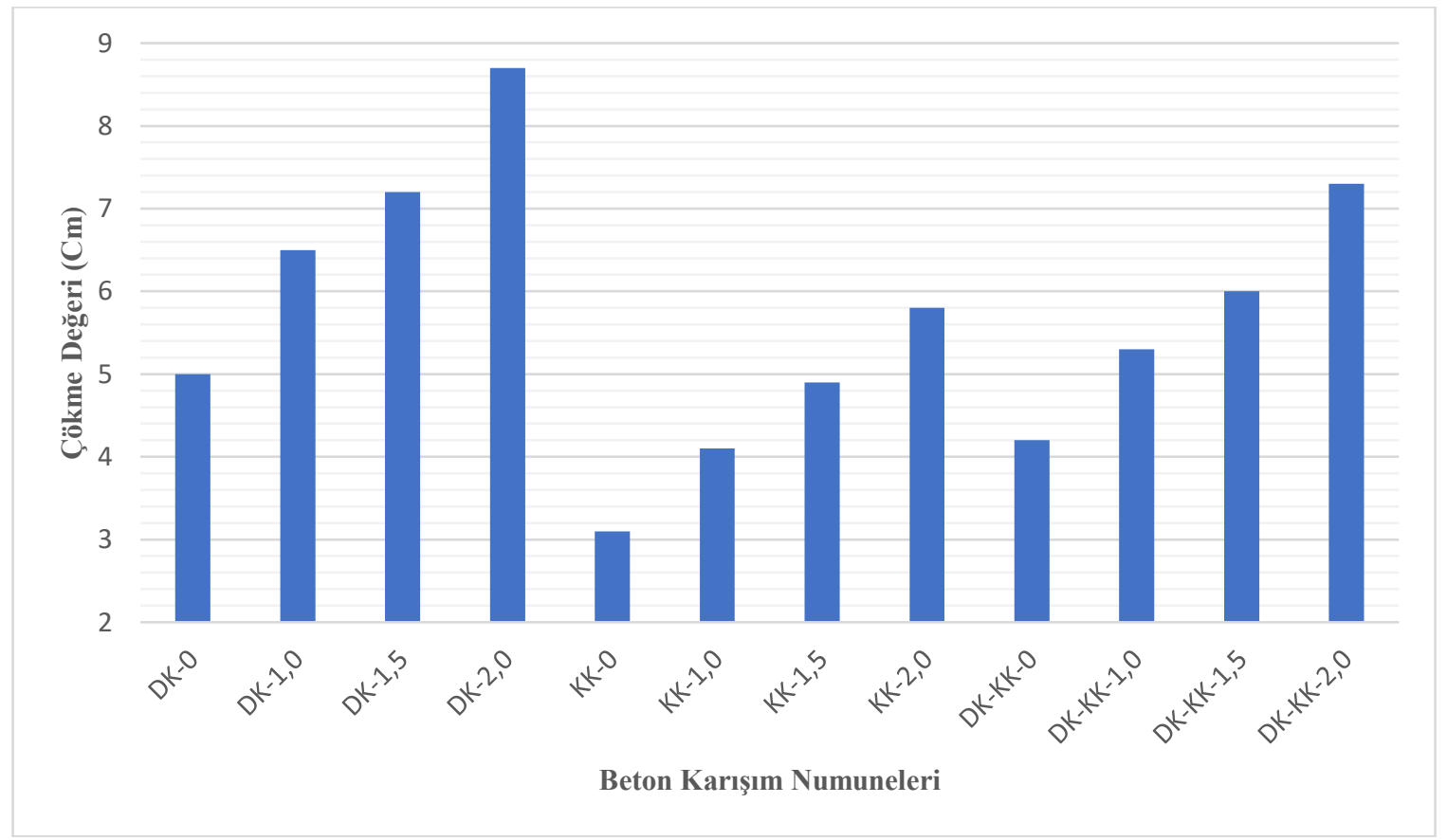

Şekil 1. Taze beton karışımları çökme ilişkisi

Doğal kum (DK), Kırma kum (KK) ve Doğal kum+ Kırma kum (DK-KK) karışımlarıyla üretilen betonların çökme değerleri birbiriyle karşılaştırıldığında Şekil 1'de görüldüğü gibi en yüksek çökme değeri DK' li karışımlarda görülürken en düşük çökme değerleri KK' 
li karışımlarda görülmüştür. Bunun nedeni, doğal kum tanesinin yüzey alanının, kırma kum tanesinin yüzey alanına göre daha küçük olmasıdır. Kırma kumun yüzey alanı ve filler malzeme miktarından dolayı karışım suyu ihtiyacı artmaktadır. Başka bir faktör ise doğal kum tanesinin yüzey alanının kırma kumun yüzey alanına göre daha pürüzsüz olmasından dolayı daha kolay işlenebilirlik göstermesidir.

Bütün taze beton karışımlarında en yüksek çökme (slump) değeri DK-2,0 olup 8,7 cm olarak ölçülürken en düşük çökme KK-0 karışımda 3,1 cm ölçülmüştür. Doğal kum ve kırma kumun (DK-KK) birlikte kullanıldığı beton numunelerinin aritmetik ortalaması KK agregalı beton numunelerine oranla \%27 fazla olup DK agregalı beton numunelerinin aritmetik ortalamasına oranla \%17 düşük çıkmıştır.

Bu sonuçlara göre doğal kumun işlenebilirliğe olumlu bir katkısı olduğu Şekil 1'de açık olarak görülmektedir.

\subsection{Sertleşmiş Betonun Özellikleri}

Sertleşmiş betonun basınç, yarmada çekme, aşınma direnci, kılcal su emme ve serbest rötre özellikler incelenmiştir. Her bir özellik için aritmetik ortalamalarının grafikleri çizilmiştir.

\subsubsection{Basınç dayanım özellikleri}

Beton tasarımıyla üretilen deney numunelerinin 7 ve 28 günlük basınç dayanımları Şekil 2' de verilmiştir.

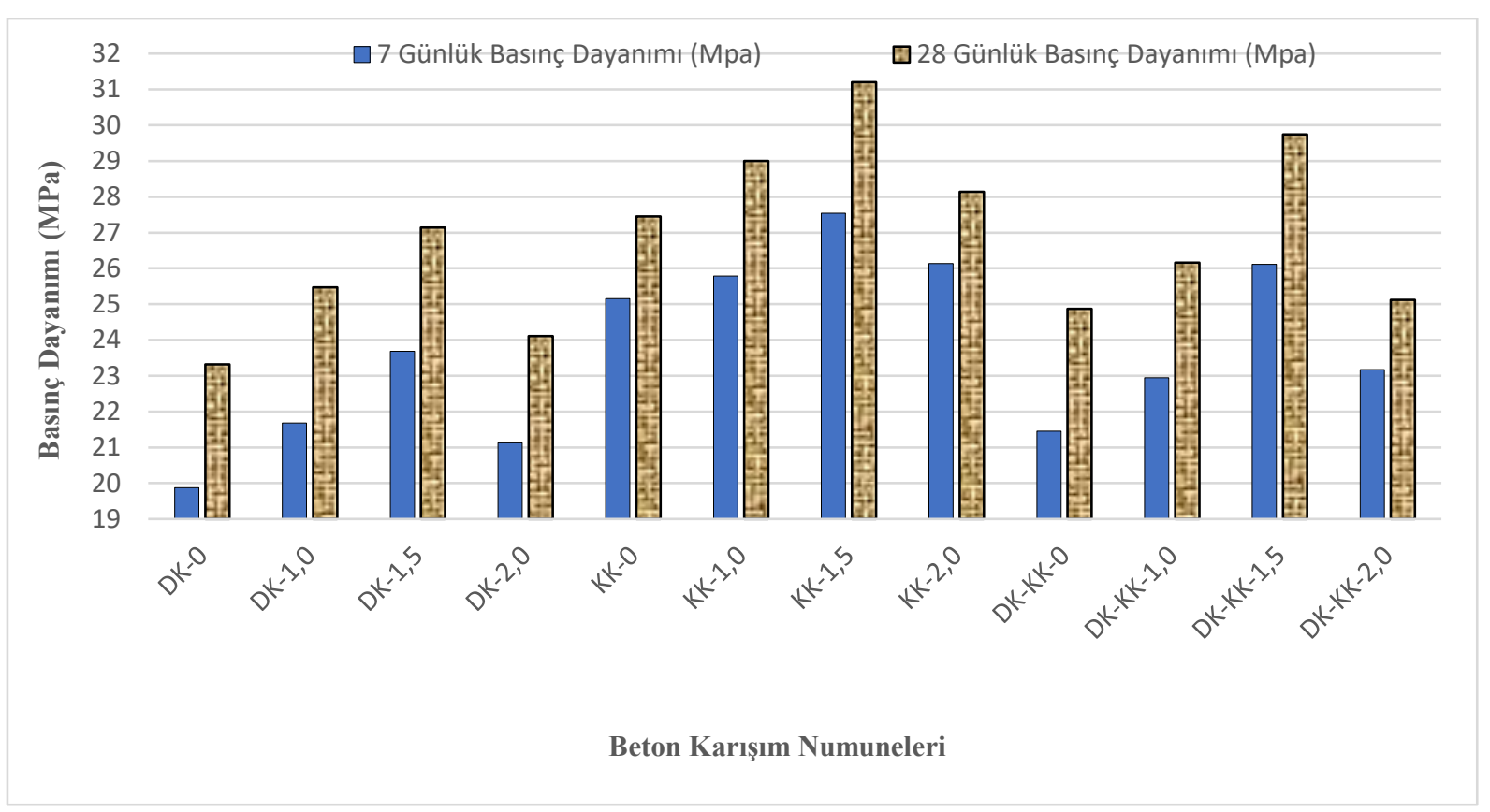

Şekil 2. Beton karışımlarının basınç dayanımı

Doğal kum (DK), Kırma kum(KK) ve Doğal kum+ Kırma kum karışımlarıyla üretilen betonların basınç dayanım değerleri birbiriyle karşılaştırıldığında Şekil 2'de görüldüğü gibi en yüksek basınç dayanımı değeri KK'lı karışımlarla üretilen beton numunelerinde görülmektedir. En düşük basınç dayanım değerleri ise $\mathrm{DK}^{`} l_{1}$ karışımlarla üretilen betonlarda görülmüştür. Basınç dayanımı değerlerinin, ince agrega cinsi bağlamında taze beton çökme değeri ile ilişkilendirmek mümkündür. Yani çökme miktarı KK karışımıyla üretilen betonun çökme değerleri en düşük idi, burada ise en yüksek basınç dayanımı vermiştir. Bunun sebebi kırma agreganın (tane yüzey şekli) çimento hamuru matrisi ile aderansının çok güçlü olması ve aynı zamanda karışımdaki şerbet suyunun diğer karışımlara göre az olmasından kaynaklandığı söylenebilir. Bütün karışımlarda en yüksek basınç dayanımı \% 1,5 oranında kimyasal katkılı karışımda elde edilmiştir. En düşük dayanımlar ise genel olarak yüksek performanslı süper akışkanlaştırıcı katkı kullanılmayan (kontrol) beton numunelerinde görülmektedir.

Karışımlarda yüksek performanslı süper akışkanlaştırıcı katkı oranı optimumdan sonra olumsuz etki göstergesi olarak, bütün karışımlarda basınç dayanımının belirli oranda düştüğü görülmüştür. Bunun nedeni, taze beton kalıba yerleştikten sonra betonda kusma meydana gelmesidir. Karışım suyunun kalıp yüzeyine çıkması sırasında agreganın yoğunluğundan dolayı oturma sonucunda segresyon meydana gelmesidir, yani homojenliğinin bozulması olarak değerlendirilmiştir. Bazı kimyasal katkı maddesi üretici firmaları, yüksek performanslı süper akışkanlaştırıcılar, plastik ve akıcı kıvamlı (yani normal hazır betonlarda) betonlarda bağlayıcının \% 1' ne kadar kullanabilmesine karşın \%2' ye kadar kullanılması durumunda birtakım sıkıntıların olabileceğini belirtilmektedir (Sika® ViscoCrete). 
DK, KK ve DK-KK kodlu numuneler arasındaki aritmetik bağıntılar incelendiğinde, KK kodlu numuneler DK kodlu numunelerden $\% 16$ fazla, DK-KK kodlu numunelerden ise \%9 az olduğu gözlenmiştir. Bu durumun ise kırma kumun doğal kumuna göre daha yoğun, daha büyük yüzey alana sahip ve boşluksuz olmasından kaynaklandığı söylenebilir.

\subsubsection{Yarmada çekme dayanım özelliği}

Üretilen betonun yarmada çekme dayanımı numunelerin basınç dayanımına paralellik göstermiştir. Beton karışım sınıflarına göre beton numuneler üzerinde yapılan yarmada çekme dayanımı deney sonuçları Şekil 3' de gösterilmiştir.

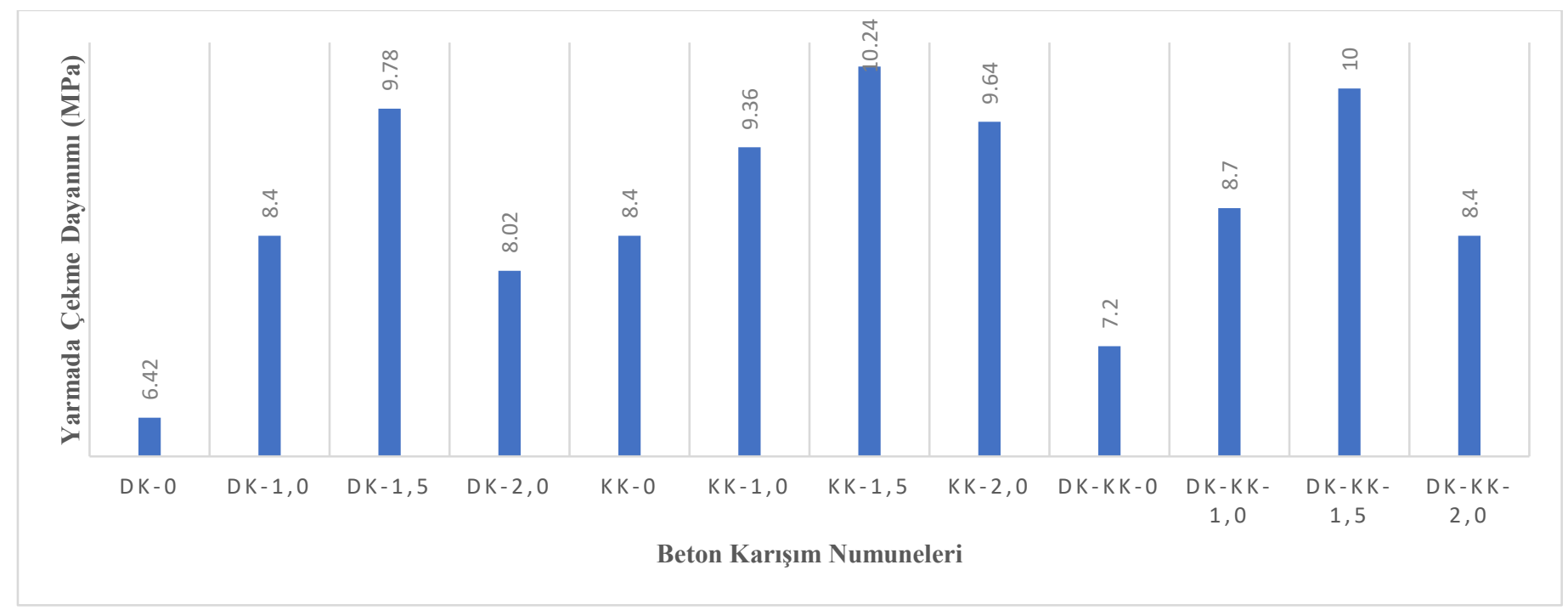

Şekil 3. Yarmada çekme dayanımı testi sonuçları

Şekil 3 incelenip analiz edildiğinde en yüksek yarmada çekme dayanımlarını KK agrega ile üretilen beton numuneleri vermiştir. Bu agrega karışımıyla ve \%1,5 yüksek performanslı süperakışkanlaştırıcı kullanılarak üretilen beton numunesinin yarmada çekme dayanımı 10,24 MPa olarak bulunmuş̧ur. En düşük yarmada çekme dayanımlarını DK karışımıyla üretilen beton örnekleri vermiştir. DK - KK agregalı beton karışım numunelerinin yarmada çekme dayanımı DK ile üretilen beton numune değerlerinden büyük olduğu belirlenmiştir. En yüksek yarmada çekme dayanımını KK karışımlı betonlar vermiştir. Bunun nedeni kırma kumlarının çimento hamuru ile aderansının güçlü olmasındandır.

\subsubsection{Aşınma direnci özellĭgi}

Aşınma dayanımı 28 günlük kür sürelerini tamamladıktan sonra her bir karışımdan 3 adet numune üzerinde aşınma deneyi yapılmış olup deney sonuçları Şekil 4' de verilmiş̧ir.

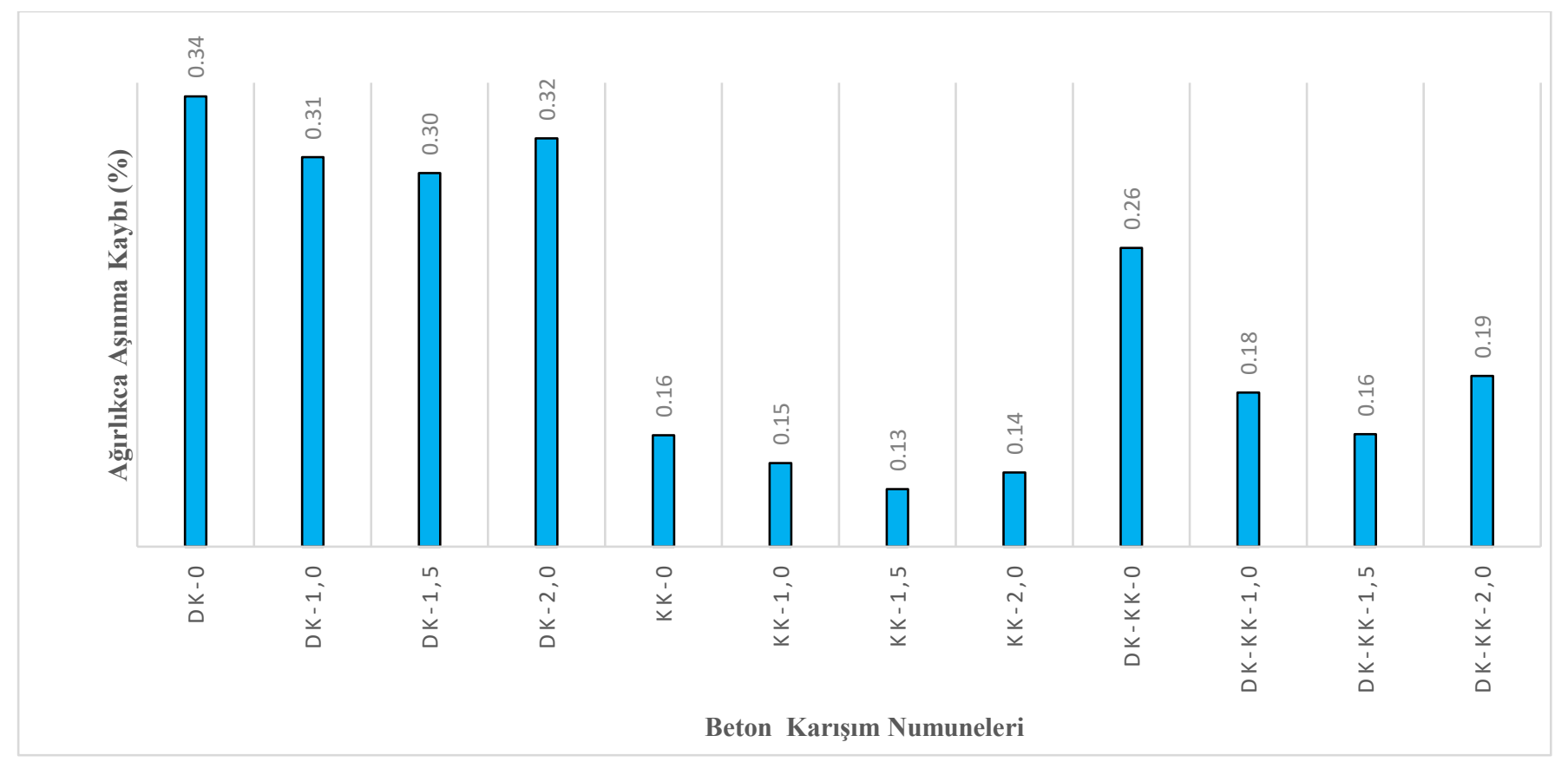

Şekil 4. Beton karışım numunelerinin aşınma kaybı 
Şekil 4'de görüldüğü gibi üretilen beton karışımlarında agrega bazında en fazla aşınma kaybı doğal kum (DK) karışımıyla üretilen beton numunelerinde görülür iken, en düşük aşınma kaybı kırma kum (KK) karışımıyla üretilen beton numunelerinde görülmektedir. Şekil 4 incelenip yüksek performanslı süper akışkanlaştıııcı bazında analiz edilirse bütün karışımlarda \%1,5 oranıyla üretilen beton numuneleri kendi agrega gruplarıyla üretilen betonlarda en düşük aşınma kaybına sahip olduğu görülmektedir.

Doğal kum karışımıyla üretilen beton numunelerinde aşınma kaybı en fazla DK-0 kodlu numunelerde $\% 0,34$ olurken, en düşük aşınma kaybı DK-1,5 kodlu numunelerde \% 0,31 olmuştur. DK ile üretilen betonların aşınma kayıpları arasında ciddi fark olmasının ana nedeni çimento hamuru ile doğal kumun aderansını kum yüzeyindeki pürüzlülüğün az olmasından dolayı düşürmesinden kaynaklandığı söylenebilir.

Kırma kum karışımıyla üretilen beton numunelerinin aşınma kaybı DK ile üretilen beton numunelerine göre paralellik göstermektedir. Burada da en fazla aşınma kaybı KK-0 numunelerde \%0,16 olurken, en düşük aşınma kaybı KK-1,5 numunelerde \%0,13 olmuştur. KK ile üretilen betonların aşınma kayıpları arasında oldukça az fark olduğu Şekil 4'de görülmektedir.

Doğal ve kırma kum karışımıyla üretilen beton numunelerinin aşınma kaybı en fazla DK-KK-0 numunelerde \%0,26 olurken, en düşük aşınma kaybı DK-KK-1,5 numunelerde \%0,16 olmuştur. DK-KK ile üretilen betonların aşınma kayıpları arasındaki fark diğer karışımlardan daha farklıdır. Bunun nedeninin, iki farklı kum çeşidinin beraber kullanılmasından kaynaklandığı söylenebilir.

\subsubsection{Kllcal su emme özellikleri}

Betonun kılcallığı, su ile temas eden numune yüzeyindeki kılcal boşluklar yoluyla yukarı kısımlara doğru kapiler çekim kuvveti ile yükselir. Bu suyun yükselmesi yani numune bünyesinde ilerlemesi birbiriyle bağlantılı boşluklu malzemelerde çok rastlanılır. Homojen malzemeler, kapiler su emmeye tabi tutulur ise, suyun malzeme bünyesinde yukarı doğru ilerlemesi sıvının Poiseuille rejimine uyduğundandır. Poiseuille rejimine göre, malzeme içerisindeki sıvının yukarı doğru çıkma hızı ile sıvının yüksekliği arasında ters ilişki vardır. Beton karışım tiplerinin kapiler su emme katsayıları Tablo 6'da verilmiştir.

Tablo 6. Beton karışımlarının kapiler su emme katsayısı

\begin{tabular}{lllllllllllll}
\hline $\begin{array}{l}\text { Beton } \\
\begin{array}{l}\text { Karışım } \\
\text { Numuneleri }\end{array}\end{array}$ & DK-0 & DK-1 & DK-1,5 & DK-2 & KK-0 & KK-1 & KK-1,5 & KK-2 & DK-KK-0 & DK-KK-1 & $\begin{array}{l}\text { DK-KK- } \\
1,5\end{array}$ & $\begin{array}{l}\text { DK- } \\
\text { KK-2 }\end{array}$ \\
\hline $\begin{array}{l}\mathrm{C} w, s \\
{\left[\mathrm{~g} /\left(\mathrm{m}^{2} . \mathrm{s}\right)\right]}\end{array}$ & 0,16 & 0,15 & 0,13 & 0,15 & 0,11 & 0,10 & 0,10 & 0,10 & 0,15 & 0,14 & 0,12 & 0,14 \\
\hline
\end{tabular}

Tablo 6 incelendiğinde, KK ile üretilen akışkanlık kazandırıcı katkı oranı 1,5 olan karışım KK-1,5 en düşük kapiler su emme miktarı elde edilmiş ve kapiler su emme katsayısı $(\mathrm{C} \mathrm{w}, \mathrm{s}) 0,10\left[\mathrm{~g} /\left(\mathrm{m}^{2} . \mathrm{s}\right)\right]$ olarak bulunmuştur. En büyük kapiler su emme KK-0 ve kapiler su emmesi katsayısı $(\mathrm{C} \mathrm{w}, \mathrm{s}) 0,11\left[\mathrm{~g} /\left(\mathrm{m}^{2} . \mathrm{s}\right)\right]$ dir. İnşaat yıkıntı atığı iri agregası ve doğal kum ve kırma kum kombinasyonuyla (DK-KK) üretilen beton numuneleri kendi aralarında kapiler su emmeleri açısından karşılaştırdığında DK-KK-1,5'den en düşük kapiler su emme miktarı elde edilmiş ve kapiler su emme katsayısı $(\mathrm{C} \mathrm{w}, \mathrm{s}) 0,12\left[\mathrm{~g} /\left(\mathrm{m}^{2} . \mathrm{s}\right)\right]$ olarak bulunmuştur. DK-KK-0 karışımıyla üretilen beton numunesinin kapiler su emmesi bu karışımların en büyük kapiler su emme katsayısı $(\mathrm{C} w, \mathrm{~s}) 0,15\left[\mathrm{~g} /\left(\mathrm{m}^{2} . \mathrm{s}\right)\right]$ dir. Beton içerisinde ki boşluğun azalması ve kompakt bir yapı oluşması numunelerin kapiler su emmesini etkilemektedir.

Doğal kumlu karışımlı numunelerin kapiler su emme katsayıları Tablo 6'da verilmiştir. Bu katsayılar sırasıyla DK-0 (Cw,s), 0,16 [g/(m $\left.\left.{ }^{2} . \mathrm{s}\right)\right]$, DK-1(Cw,s) $0,15\left[\mathrm{~g} /\left(\mathrm{m}^{2} . \mathrm{s}\right)\right]$, DK-1,5 (Cw,s) $0,13\left[\mathrm{~g} /\left(\mathrm{m}^{2} . \mathrm{s}\right)\right]$, ve DK-2(Cw,s) $0,15\left[\mathrm{~g} /\left(\mathrm{m}^{2} . \mathrm{s}\right)\right]$, olduğu görülmektedir.

Akışkanlaştıııcı katkı oranı \%2 (DK-2) olan numunelerin kılcal su emmeleri diğer akışkanlaştırıcılar arasında en yükseğidir. Bunun sebebi azda olsa taze beton yerleştirildikten sonra kusma meydan gelmesi ve kılcal boşlukların meydana gelmesidir. Buda kapiler su emmeyi artırmaktadır.

Yıkıntı atığından elde edilen iri agrega ve doğal kum karışımıyla üretilen DK-1,5' den en yüksek kapiler su emme miktarı elde edilmiştir. DK-0' da ise en düşük kapiler su emme meydana gelmiştir. Kırma kumla (KK) ile üretilen beton numunelerinin DK numunelerinden daha az kapiler su emdiği görülmektedir. Kapiler su emme, aşınma kaybı ve basınç dayanımı özelliklerinin aynı numunelerde birbirine paralel olduğu gözlemlenmiştir.

Bu çalışmada, karışımlarla üretilen numunelerin kapiler su emme, aşınma kaybı, yarmada çekme ve basınç dayanımı özellikleri aynı numunelerde birbirine paralellik göstermiş̧ir.

Araştırmada kullanılan numunelerin kapiler su emme test sonuçlarına bağlı olarak kılcal su emme miktarı- kapiler su emme süresi ilişskisi ise Şekil 5' de verilmiştir. 


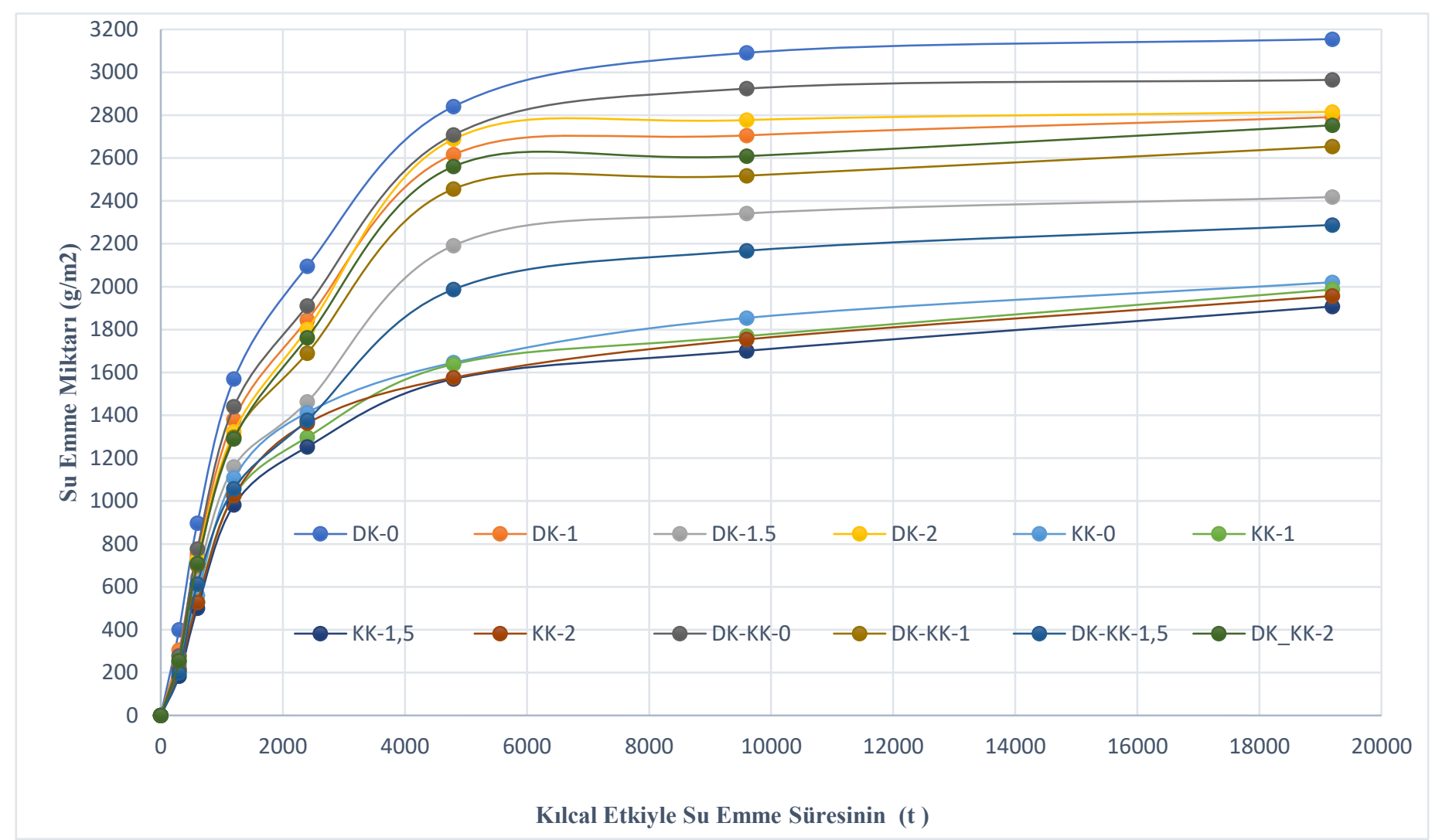

Şekil 5. Beton karışımlara tiplerinin kılcal su emme grafiği

Şekil 5 incelendiğinde, bütün numunelerde ilk 1200 saniyede (20 dakika) kapiler su emme hızı oldukça yüksek ve birbirlerine çok yakın olduğu görülmektedir. Kapiler su emme süresi 2400 saniyeye (40 dakikaya) ulaştı̆̆ında kapiler su emme hızı karışımda kullanılan ince agrega ve katkı oranına bağlı olarak değişmektedir. Su emme süresi 4800 saniyeye (80 dakikaya) ulaştığında kapiler su emme hızı zamana bağlı olarak yatay doğrultuya yaklaşmıştır. Karışımda kullanılan ince agrega ve katkı oranına bağlı olarak su emmedeki farklılığın büyük ölçüde ortaya çıktığı açıkça şekilde görülmektedir. Kapiler su emme süresinin 19200 saniyeye (320 dakikaya) ulaştığında tam olmasa da yatay doğrultuya oldukça yaklaştığı görülmüştür.

\subsubsection{Serbest rötre özelliği}

Rötre deneyleri kapsamında her bir karışım için hazırlanan numunelerin su içindeki serbest boy değişimi incelenmiştir. Serbest rötre numune uzunluğunun en kesit boyutlarından daha büyük olması halinde rötrenin yalnız uzunluk doğrultusunda meydana geleceği kabul edilmiş ve buna göre lineer deformasyon ölçümleri yapılmıştır (Türker \& Felekoğlu, 2004). Bu çalışmada elde edilen sonuçlar iki grafik şeklinde verilmiştir. İlk serbest rötre grafiği olan Şekil 6' da günlük bazda ölçülen yüzdesel boy değişim verileri ile birlikte verilir iken, ikinci grafik olan Şekil 7'de deney ilk boy ölçümü ile son ölçüm farkının yüzdesi olarak verilmiştir.

Şekil 6 incelenip değerleri analiz edildiğinde DK-0 karışımlı numunelerin ilk günkü ortalama boy değişimi $-0,07$ iken 14 dördüncü gün $-0,04$ olduğu görülmektedir. Bunun yanında 8 güne kadar boyda büzülme meydana gelirken bu günden sonra numune boyunda uzamaya geçiş başlamıştır. Diğer DK ile yapılan karışım numunelerde aynı paralel davranış gözlenmiştir.

KK-0 karışımlı numunelerin ilk günkü boy değişimi -0,03 iken 14 dördüncü gün 0,063 olduğu görülmektedir. Numunelerin ilk 8 güne kadar boyda büzülme şeklinde serbest rötre meydana gelirken 9.cu günden sonra numunelerde serbest rötre boy uzaması geçiş başlamıştır. Diğer KK ile yapılan karışım numunelerde aynı paralel davranış gözlenmiştir. En büyük serbest uzama rötresi KK-1,5 karışımlı beton numunelerinde meydana gelmiştir. 


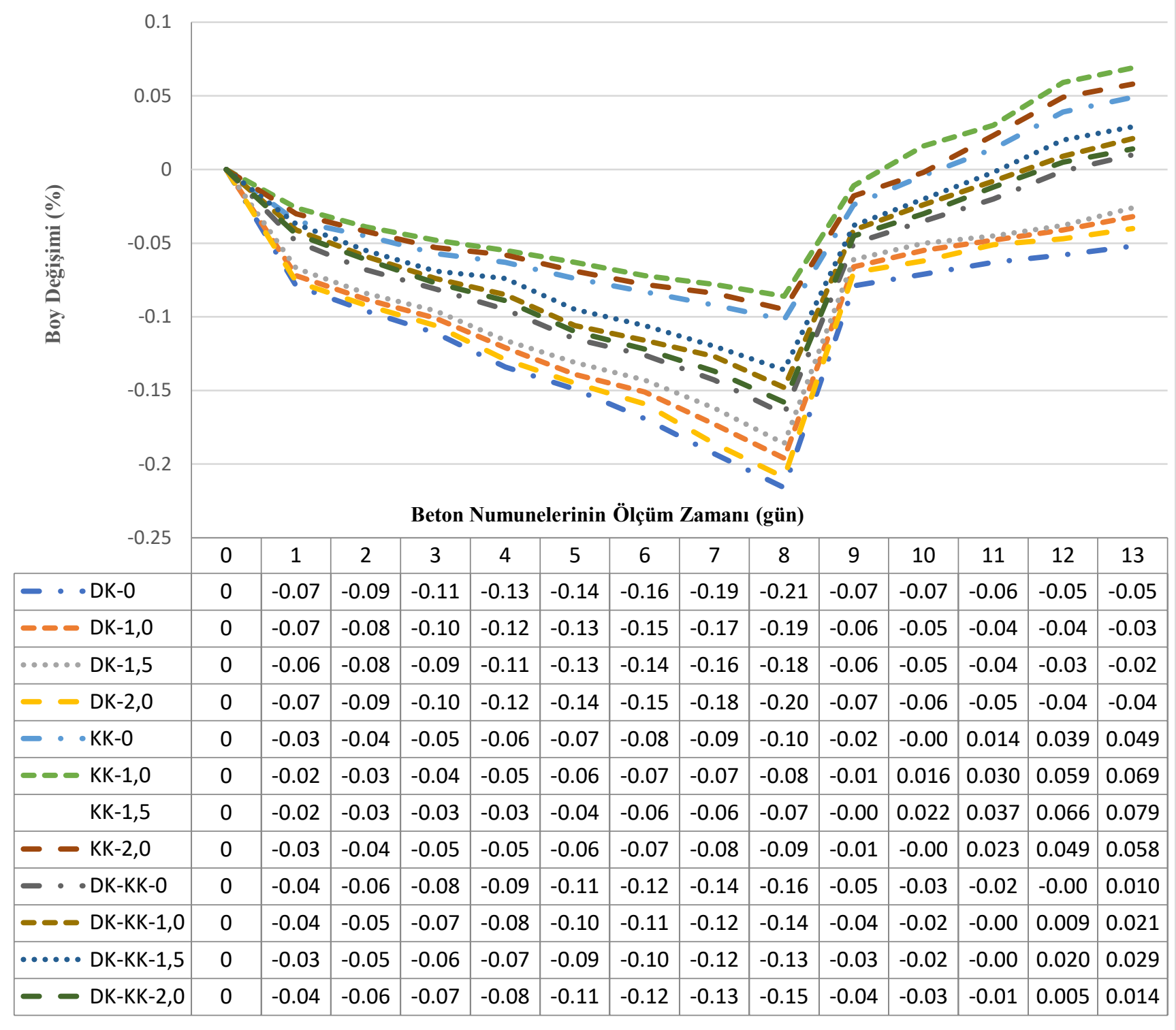

Şekil 6. Bütün karışımlara ait serbest rötre yüzde değerleri ve grafiğgi

DK-KK kombinli karışımların serbest rötre yüzdeleri Şekil 6 incelenip değerleri analiz edildiğinde DK-KK-0 karışımlı numunelerin diğer karışımlarda olduğu gibi ilk günkü ortalama boy değişimi $-0,04$ iken 14 dördüncü gün 0,020 olduğu görülmektedir. Bunun yanında 8 güne kadar boyda büzülme meydana gelirken bu günden sonra numune boyunda uzamaya geçiş başlamıştır. Diğer DK-KK kombinli karışım numunelerinde de aynı paralel davranış gözlenmiştir.

Su içinde bekleyen numunelerin hepsinde çimento jelleri tarafından emilen su nedeniyle belli bir yaşa kadar şişme (negatif rötre) meydana gelmiştir. DK ile üretilen betonların rötre okuma kayıtlarında ilk günlerde negatif rötrenin meydana geldiği ve deneyin son günlerine doğru bu değişimin minimum değere ulaştığı gözlenmiştir. Şekil 7 incelenip analiz edildiğinde, DK numunelerinin son gündeki negatif değişim yüzdesi yanında, KK ve DK-KK 'lı karışımlar ile üretilen numunelerin boy değişiminde pozitif bir artış görülmektedir. Bu artışlar KK ile üretilen karışımlarda en yüksek seviyeye ulaşmıştır. Beton karışımlarının basınç dayanımı, kapiler su emme özelikleri ile serbest rötre ilişkilendirildiğinde betonun boşluklu yapısı ile bu özelikleri arasında bağıntı kurmak mümkündür. Boşluğu fazla olan betonun numunesinin basınç dayanımı düşük, kapiler su emmesi yüksek, boy değişimi azdır. Dolayısı ile numune içindeki boşluk ile boy değişimi arasında bir ilişki kurulabilinir. Boşluğu az olan numunenin basınç dayanımı yüksek, serbest rötresi yüksek, kılcal su emmesi düşüktür. 


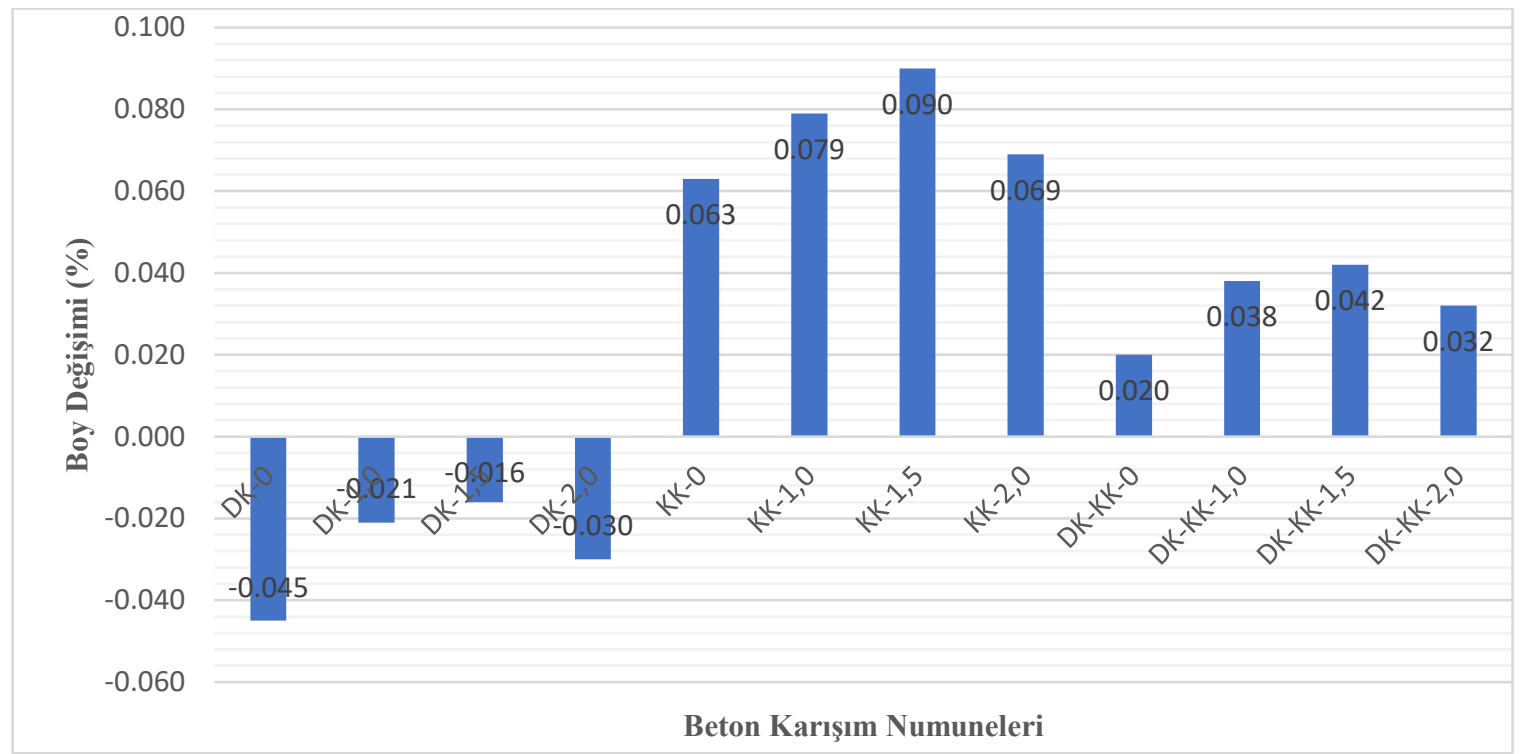

Şekil 7. Beton karışım numunelere ait toplam boy değişim grafiği

Şekil 7 incelenip analiz edildiğinde boy değiş̧im oranın en az olduğu numuneler KK kodlu numuneler olup, en fazla boy değişimi sergileyen numunelerin ise DK kodlu numuneler olduğu dikkat çekmektedir.

Maksimum boy değişimi gösteren numune KK-1,5, minimum boy değişimi gösteren numune ise DK-1,5 olarak görülebilmektedir.

Suda bekleyen çimento harçlarınca emilen suyun belli bir yaşa kadar negatif (şişme) rötre oluşturduğu ve 8. Günün sonunda minimum değere ulaştı̆̆ gözlenmiştir. Daha sonra numuneler büzülerek negatif rötre normal rötreye dönüşmüş ve 14.cü günün sonunda 1 . gündeki değerlere ulaşıp, geçmiştir.

\section{Sonuç ve Öneriler}

Doğal kum, betonun işlenebilirliğini kolaylaştırmaktadır. Kırma kum, betonun işlenebilme yeteneğini olumsuz etkilemektedir. Doğal ile kırma kum karışımıyla üretilen betonun işlenebilirliği kırma kumla üretilen betondan yüksek, doğal kum karışımıyla üretilen beton işlenebilirliğinden ise düşüktür.

Karışımda kullanılan süperakışkanlaştırıcı oranı artıkça bütün karışımların işlenebilirliği artmıştır.

Doğal kum karışımıyla üretilen betonların özellikleri diğer karışımlara göre en düşük performansa sahiptir. DK-1,5 karışımı ile üretilen betonların ise daha yüksek olduğu saptanmıştır.

Kırma kum karışımıyla üretilen betonların özellikleri diğer karışımlara göre en yüksek performansı göstermiştir. KK-1,5 karışımlı betonun mekanik ve fiziksek özellikleri diğer kumlarla üretilen betonlardan daha yüksektir.

Doğal + kırma kum karışımıyla üretilen betonların özellikleri kırma kum ile üretilen betonlardan düşük iken doğal kum ile üretilen betonlardan yüksektir.

Sonuç olarak; iri agrega yıkıntı atığı ince agrega kırma kum ve \% 1,5 yüksek performanslı süper akışkanlaştırıcı oranıyla üretilen betonların mekanik ve fiziksel özelikleri istenilen performansı sağlamıştır.

İnşaat yıkıntı atığı olan molozların içinde, kil (toprak) bulunması durumunda geri dönüşüm agregası kullanılmadan önce kilden arındırılmalıdır. GDA' nın, ince agregalar ile kullanılması durumunda kireç, alçı ve boya gibi atıklara karşı yıkanmalı veya beton içinde zararlı atıkların bulunması durumunda bu malzemelere karşı gerekli önlemler alınmalıdır.

\section{Referanslar}

ASTM C944/C944M-19. (2019). Standard Test Method for Abrasion Resistance of Concrete or Mortar Surfaces by the Rotating-Cutter Method.

Çelik B. (2001). Recycled Aggregate Concrete at Elevated Temperatures. Doktora Tezi. Boğaziçi Üniversitesi, İstanbul 
Demirel C., Toklu K. \& Şimşek O. (2015). Geri dönüşüm agregasının beton üretiminde kullanılabilirliği ve sürdürüleblirlik açısından değerlendirilmesi. 2nd International Sustainable Buildings Symposium. 42-47 Retrieved from http://www.isbs2015.gazi.edu.tr/ belgeler/bildiriler/42-47.pdf

Demirel C. \& Şimşek O. (2014). C30 sınıfı atık betonun geri dönüşüm agregası olarak beton üretiminde kullanılabilirliği. S.Ü. Müh. Bilim ve Teknik. Dergisi. 2(2), 45-54. Retrieved from http://sujest.selcuk.edu.tr/sumbtd/article/view/256/380

Devlet Planlama Teşkilatı. (2000). DPT VIII. Beş Yıllı Kalkınma Planı (2001 -2005), Ankara. Retrieved from https://www.sbb.gov.tr/wp-content/uploads/2018/11/08_Ulastirma.pdf

Devlet Planlama Teşkilatı (DPT). (2007). Dokuzuncu Kalkınma Planı 2007-2013, Ankara. Retrieved from https://www.sbb.gov.tr/wp-content/uploads/2018/11/Dokuzuncu-Kalk\%C4\%B1nma-Plan\%C4\%B1-2007-2013\%E2\%80\%8B.pdf

Durmuş G., Şimşek O. \& Can Ö. (2009). Geri dönüşüm agregalardan üretilen farklı sınıflardaki betonun mühendislik özelliklerinin belirlenmesi. 5. Uluslararası Illeri Teknolojiler Sempozyumu (IATS'09) 2103-2106. Retrieved from https://docplayer.biz.tr/7924394Iats-09-edited-by-mustafa-acarer-halil-ibrahim-demirci-cevdet-gologlu-copyright-2009-iats-09-isbn-978-605-60681-0-2.html

Esra, Ö. \& Şenol, Y. (2008). İnşaat yıkıntı atıklarının yönetimi ve planlanan istanbul modeli. Kent Yönetimi, İnsan ve Çevre Sorunları "08 Sempozyumu, 413-419, 02-06 Kasım 2008, İstanbul. Retrieved from https://istac.istanbul/contents/44/cevremakaleleri_130838595529678877.pdf

Lauritzen, K. E. (1994). Reuse of Concrete and Masonary. Great-Britain: St. Edmundsbury Pres.

Kou S.C., Poon C.S. \& Chan D.C. (2007). Influence of fly ash as cement replacement on the properties of recycled aggregate concrete. ASCE Journal of Material In Civil Engineering, 19(9), 709-715. https://doi.org/10.1061/(ASCE)0899-1561(2007)19:9(709)

Maçin, K. E., \& Demir, İ. (2018). Kentsel dönüşüm sürecinde istanbul'da inşaat ve yıkıntı atıkları yönetimi. Adıyaman Üniversitesi Mühendislik Bilimleri Dergisi, 9(2018), 188-201 Retrieved from http://dspace.adiyaman.edu.tr:8080/xmlui/handle/20.500.12414/527

Ölmez E., \& Yıldız Ş., (2008). İnşaat yıkıntı atıklarının yönetimi ve planlanan İstanbul modeli. Kent Yönetimi, İnsan ve Çevre Sorunlari"08 Sempozyumu 02-06 Kasım 2008

Resmi gazete (2012) . https://www.resmigazete.gov.tr/eskiler/2012/05/20120531-1.htm erişim tarihi 10.02.2021

Süme E. (2016). Geri dönüşüm agregasının beton yol kaplamasında kullanılabilirliği. Yüksek Lisans Tezi. Karadeniz Teknik Üniversitesi, Trabzon

Sika (2007) ViscoCrete® ${ }^{\circledR}$-SF 18 Üçüncü nesil yüksek performanslı beton ve harç katkısıdır. Ürün Bilgi Föyü. https://heris.com.tr/Resimler/2d9557f65cSika\%20Viscocrete\%20SF\%2018\%2020072201\%20TR.pdf

Sonawane, T.R., \& Pimplikar, S.S.,(2013) “Use of Recycled Aggregate Concrete”, Journal of Mechanical and Civil Engineering, 22781684, pp: 52-59.

Şimşek, O. (2020). Beton ve Beton Teknolojisi (5. baskı). Ankara, Seçkin Yayıncılık San. ve Tic. A.Ş.

TS EN 933-1. (2015). Agregaların geometrik özellikleri için deneyler-Bölüm 1: Tane büyüklüğü dağılımının tayini - Eleme yöntemi, TSE. Ankara

TS EN 1097-6. (2015). Agregaların mekanik ve fiziksel özellikleri için deneyler-Bölüm 6:Tane yoğunluğunun ve su emme oranının tayini, TSE. Ankara

TS EN 933-3. (2015). Agregaların geometrik özellikleri için deneyler - Bölüm 3: Tane şekli tayini - Yassılık endeksi, TSE. Ankara

TS EN 1097-2. (2015). Agregaların mekanik ve fiziksel özellikleri için deneyler bölüm 2: Parçalanma direncinin tayini için metotlar, TSE. Ankara

TS EN 933-9+A1:2013. (2014). Agregaların geometrik özellikleri için deneyler - Bölüm 9: İnce malzeme tayini - Metilen mavisi deneyi, TSE. Ankara

TS 802 (2016). Beton karışım tasarımı hesap esasları, TSE. Ankara 
TS EN 12350-2, (2019). Beton - Taze beton deneyleri - Bölüm 2: Çökme (slump) deneyi, TSE. Ankara

TS EN 12390-3, (2019). Beton - Sertleşmiş beton deneyleri - Bölüm 3: Deney numunelerinin basınç dayanımının tayini, TSE. Ankara

TS EN 772-11, (2012). Kâgir birimler - Deney yöntemleri - Bölüm 11: Betondan, gaz betondan, yapay ve doğal taştan yapılmış kâgir birimlerde kapiler su emme ve kil kâgir birimlerde ilk su emme hızının tayini, TSE. Ankara

TS ISO 1920-8, (2011). Beton deneyleri - Bölüm 8: Şantiyede veya laboratuvarda hazırlanan numuneler için betonun kuruma büzülmesinin tayini, TSE. Ankara

TS EN 12390-6, (2010). Beton - Sertleşmiş beton deneyleri - Bölüm 6: Deney numunelerinin yarmada çekme dayanımının tayini, TSE. Ankara

Türkel, S , \& Felekoğlu, B . (2004). Aşırı dozda akışkanlaştırıcı kimyasal katkı kullanımının taze ve sertleşmiş betonun bazı özellikleri üzerine etkileri. Dokuz Eylül Üniversitesi Mühendislik Fakültesi Fen ve Mühendislik Dergisi, 6 (1) , 77-89 . Retrieved from https://dergipark.org.tr/tr/pub/deumffmd/issue/40877/493539 